\title{
Winter Wind Chill Climatology for the High Plains Region
}

\author{
Holly B. Lussenden \\ East Carolina University, Greenville, NC
}

Natalie A. Umphlett ${ }^{1}$

High Plains Regional Climate Center, Lincoln, NE

Martha D. Shulski

High Plains Regional Climate Center, Lincoln, NE

Daniel Ebert

Department of Computer Science and Engineering, University of Nebraska-Lincoln, Lincoln, NE

\author{
Journal of Service Climatology \\ Volume 7, Number 1
}

A Refereed Journal of the American Association of State Climatologists

\footnotetext{
${ }^{1}$ Corresponding author address: Natalie Umphlett, High Plains Regional Climate Center, University of NebraskaLincoln, 712 Hardin Hall, 3310 Holdrege Street, Lincoln, NE 68583.

E-mail: numphlett2@unl.edu
} 


\begin{abstract}
:
During the winter months in the High Plains region of the United States, wind chill temperatures can reach dangerous levels for humans and animals. Knowing the frequency in which extreme wind chill temperatures occur could help forecasters know when to issue wind chill advisories and also the general public understand just how rare, or common, certain wind chill temperatures are. A climatology spanning a 37-year period was created using data from 57 stations in and around the plains portion of the High Plains region from the Integrated Surface Hourly Database at National Climatic Data Center (NCDC). These climatologies were completed for December, January, February, and the winter season as a whole, for the number of hours and days in which wind chills reach certain thresholds. Also included is an all-time low wind chill value by location. As one might expect, results show that some of the most extreme and more frequent low wind chill temperatures in the region occur in eastern North Dakota and northwestern Minnesota. In this area, several days per year can reach $-40^{\circ} \mathrm{F}$ or lower, a temperature at which frostbite can occur within minutes. The highest number of wind chills less than or equal to $-10^{\circ} \mathrm{F}$ occurred in January, with December and February having similar distributions of wind chill occurrence.
\end{abstract}




\section{Background}

The low temperatures and high winds associated with typical winter conditions in the central and northern tiers of the U.S. Great Plains can combine to make the severity of the winter seem even worse. This sensation is called the wind chill temperature; a value that is derived from both temperature and wind speed. The wind chill temperature has also been referred to as the “apparent temperature” as it is a better indicator of how cold a person actually feels outside in the winter due to the combination of low temperatures and high winds.

The concept of a “wind chill temperature” was formulated by Siple and Passel (1945) during a United States Antarctic Expedition in 1939-41. They measured the time it took 250 grams of water contained in a pyrolin cylinder suspended above the ground to freeze under the cold and windy conditions of Antarctica. A Wind Chill Index (WCI) was created from this experiment - a number representing the rate of cooling per unit surface area of the cylinder. For many years, this index had been accepted and used. More recently, however, controversy involving the WCI and its accuracy surfaced as it was found that the WCI highly exaggerated the chilling effect of the wind. The exaggeration was caused by various factors, such as the small size of the cylinder, the use of water to determine heat loss, not considering wind speeds less than $2.2 \mathrm{~m} \mathrm{~s}^{-1}$ or more than $17.9 \mathrm{~m} \mathrm{~s}^{-1}$, and wind speed observations taken at $10 \mathrm{~m}$ height (too high for human exposure). These shortcomings led to a demand for an improved wind chill temperature calculation.

By the 1970s, the Wind Chill Equivalent Temperature (WCT), which was considered an improvement over the WCI, was in use by much of North America. However, it was believed that this index, too, had flaws, namely the exaggeration of the effects of the wind (Osczevski 2000; Bluestein 1998; Kessler 1993; Steadman 1971). Later, in 2000, researchers from North 
America (including scientists from the U.S. National Weather Service (NWS) and the Canadian Weather Service) met to discuss the WCT chart and develop a new, more scientifically valid, WCT chart. Work about heat transfer principles by Oszcevski (1995) and Bluestein and Zecher (1999) provided the best qualitative, conclusive research that the "new" WCT chart could be based on to attain more accurate WCTs. By November 2001, that new WCT chart was implemented in the United States and Canada. The new chart was an improvement, however more recent studies indicate a need for improvements still (Ahmad and Boraas 2012; Shitzer and Tikuisis 2012).

Although much research exists about the formulation and refinement of the calculation of wind chill for humans (e.g. Moore and Semple 2011; Osczevski 1995) and animals (Mader et al. 2010; Ames and Insley 1975) research on the climatology of wind chills is minimal and varied in subject. One study looked at Alaskan and Canadian wind chill extremes from 1953-1993 for 15 stations (Keimig and Bradley 2002). It was concluded that over this time period changes in apparent temperature in the afternoon hours were larger than changes in the actual air temperatures. Another study looked at the percentage of observations with wind chills below a given threshold for December through February (Rieck and Binau 2010). The spatial distribution of the study covers a large portion of the United States - from Utah to Ohio and from the U.S.Canadian border south to Kansas. As expected, the northern Plains, including North Dakota, South Dakota, and portions of Minnesota, had the highest percentage of observations with wind chill values from $-20^{\circ} \mathrm{F}$ to $-40^{\circ} \mathrm{F}$.

The motivation to pursue this study, which is similar in nature to Rieck and Binau (2010), is the demand for a user-friendly wind chill climatology product. Each winter, the High Plains Regional Climate Center (HPRCC) receives requests for climatic wind chill data. While the 
previous study is useful to many, it may be difficult for the general public and media outlets to understand the format in which the results were presented - percentage of observations with wind chills below a certain threshold. Beyond the desire to help clients, knowing the average wind chill temperatures for the region will be a useful tool for operational users such as service climatologists and NOAA weather forecasters. Ultimately, operational meteorologists would be better equipped as to when to issue wind chill advisories. Populations that are particularly vulnerable to cold exposure, including those that work outside, would benefit from this enhanced capability. Understanding wind chill frequencies is also useful for livestock health and production as it is related to exposure limits. As such, this study illustrates the distribution of wind chill temperatures for the winter months across the High Plains region of the United States categorized by days and hours. Also shown are WCT frequency distributions for several locations.

\section{Methodology}

The target area of the study was the High Plains region, which includes the plains of Colorado and Wyoming, Kansas, Nebraska, South Dakota, and North Dakota. Hourly observations from the winter months (December, January, and February) were obtained from the Integrated Surface Hourly (ISH) dataset at the National Climatic Data Center (National Climatic Data Center, 2010) for locations across the region as well as surrounding areas (in order to minimize edge effects for visualization purposes). Although this region experiences low wind chills outside the climatological winter months, these 3 months were selected due to the low percentage of wind chill observations in November and March. For instance, in the Dakotas, of all the observed hourly wind chill values of $-10^{\circ} \mathrm{F}$ or less, only 4 percent of those observations occurred in November and 6 percent occurred in March. The observations used in this study 
originated from stations within the Automated Surface Observing System (ASOS) and Automated Weather Observation Stations (AWOS) networks. Historical weather observations from 1973-2010 were collected for use in this study. Although observations were available prior to 1973, many stations do not have consistent records during that time frame. For example, many stations have hourly observations dating back to 1948 or earlier, but there was a stretch of time in the 1960s in which three-hourly observations were taken. In addition, placement of instruments varied from location to location. However, by January 1973, all stations reported observations on the hour and were updated to the current specifications for height of instruments (10 m for anemometers and $2 \mathrm{~m}$ for thermometers).

The data required processing before any analysis could be performed. The ISH data retrieval system often returns multiple observations for each hour, even if selecting only the "on the hour" observations. However, only one observation per hour was required for this study so "duplicate" observations were filtered from the data stream. Since most stations report just before the hour, the observation that was consistent throughout the time period was used. For instance, if a station which normally reports at 10:54 UTC also had a valid observation at 11:00 UTC, the 11:00 UTC observation was eliminated from the calculation. The "duplicate" observation was only used when the preceding observation was missing. Next, the filtered data went through a three-step quality control process (Shulski and You 2011). The first step included a threshold test, where observations outside of the normal range were flagged. The process also checked for step changes, where consecutive observations were checked for large differences. The final step was a persistence check, where observations were checked for too high or too low variability. Limits for each of these tests were based on the climatology of each station. Once the filtered and quality controlled dataset was complete, the stations could be selected for the study. 
Out of 64 stations that were filtered and quality controlled, only 57 met a threshold of $70 \%$ data availability (Figure 1). Although a more stringent 85\% data availability threshold was chosen initially, 70\% data availability was allowed in order to fill in gaps for the best spatial representation.

Wind chill temperatures were computed using the new wind chill equation adopted by the NWS (Osczevski and Bluestein 2005):

Wind Chill Temperature $\left({ }^{\circ} \mathrm{F}\right)=35.74+0.6215 \mathrm{~T}-35.75\left(\mathrm{~V}^{0.16}\right)+0.4275 \mathrm{~T}\left(\mathrm{~V}^{0.16}\right)$

where $\mathrm{T}$ is the temperature $\left({ }^{\circ} \mathrm{F}\right)$ and $\mathrm{V}$ is the wind speed $\left(\mathrm{mi} \mathrm{h}^{-1}\right)$; or the same equation in metric units:

Wind Chill Temperature $\left({ }^{\circ} \mathrm{C}\right)=13.12+0.6215 \mathrm{~T}-11.37\left(\mathrm{~V}^{0.16}\right)+0.3965 \mathrm{~T}\left(\mathrm{~V}^{0.16}\right)$

where $\mathrm{T}$ is the temperature $\left({ }^{\circ} \mathrm{C}\right)$ and $\mathrm{V}$ is the wind speed $\left(\mathrm{km} \mathrm{h}^{-1}\right)$. Wind chill temperatures were then categorized by various thresholds and frequencies (Table 1). If at least one hour in a given day has a wind chill value at or below a specific threshold, then that day would count as a wind chill day. Spatial analysis of the wind chill temperatures used an in-house mapping tool of the HPRCC, KMAP, which is similar to the Grid Analysis and Display System (GrADS). KMAP spatially interpolates surface observations using the Cressman objective analysis technique and has been thoroughly tested for accuracy in the region (Cressman 1959).

\section{Results and Discussion}

The distribution of wind chill frequencies shows a characteristic north-south gradient. In general, frequencies of low wind chill temperatures are much greater in the northern part of the region than the southern. For example, the frequency with wind chill temperatures less than or equal to $-10^{\circ} \mathrm{F}$ is $0-10$ days per year in southern Kansas (Figure 2). However, in North Dakota 
the frequency rises to 30-50 days per year, which is primarily due to the north-south temperature gradient. Further, frequencies are greatest around the border between North Dakota and Minnesota and into northern Minnesota. For instance, western North Dakota has frequencies of 25-35 days per year with wind chills less than or equal to $-10^{\circ} \mathrm{F}$ while eastern North Dakota has frequencies of 40-50 days per year.

When looking at the extreme end of the wind chill temperatures, the days per year with wind chills less than or equal to $-40^{\circ} \mathrm{F}$ (Figure 3), the same pattern is apparent, however the frequencies change dramatically. Southern Kansas experiences 0 days per year on average with wind chills less than or equal to $-40^{\circ} \mathrm{F}$ and, on average, North Dakota has these wind chills 2-8 days per year. The same horizontal gradient is present in North Dakota with the highest frequency of wind chill temperatures less than or equal to $-40^{\circ} \mathrm{F}$ occurring on the North DakotaMinnesota border. These frequencies are much lower because extremely low temperatures are often accompanied by calm winds.

As one would expect, the hourly climatology has much higher frequencies at which low wind chill temperatures occur; however, the same pattern emerges in the hourly maps. The number of hours in which wind chill temperatures are less than or equal to $-10^{\circ} \mathrm{F}$ occur is less than 100 in Kansas and Colorado, but greater than 400 in most parts of North Dakota (Figure 4). Again the border region of North Dakota and Minnesota has the highest frequency of hours with wind chill temperatures less than or equal to $-10^{\circ} \mathrm{F}$. Northern Minnesota experiences upwards of 700 hours of $-10^{\circ} \mathrm{F}$ or lower wind chill occurrences per climatological winter. In fact, Winnipeg, Canada (one of the edge stations used in the study) averages 880.5 hours per winter with wind chill temperatures below that threshold. Frequencies change when looking at the hourly climatology of the winter months with wind chills at or below $-40^{\circ} \mathrm{F}$ (Figure 5). The frequency 
changes to 50-55 hours per year that northern Minnesota experiences those wind chill temperatures.

Record low wind chill temperatures were compiled as well (Figure 6). Overall, the shape of the contoured map is similar to the other maps with the same north-south gradient of the wind chills. As expected, the lowest, most extreme wind chills occurred in the northern part of the region. For instance, in North Dakota the record low wind chill temperatures were $-59^{\circ} \mathrm{F}$ or lower, whereas, in Kansas, the record low wind chill for the entire state was only $-35^{\circ} \mathrm{F}$. All but seven of the records occurred in January and no records occurred in December. One particular day stood out as having the most record low wind chills - January 10, 1982. An Arctic airmass brought extremely low temperatures and windy conditions to the region, which led to the records on January 10. January 1982 was overall a cold and stormy month for much of the United States and many locations in and around the region had one of the coldest Januarys on record at that time (Wagner 1982). Although many record low wind chills occurred in 1982, one winter season stands out as having a particularly high number of wind chill hours at or below $-10^{\circ} \mathrm{F}$ - the winter of 1978-1979. For instance, Fargo, North Dakota had 1481 hours at or below $-10^{\circ} \mathrm{F}$ that winter (Figure 7). This is nearly 25\% more hours than the winter of 1996-97 which is the winter with the second highest number of hours at or below $-10^{\circ} \mathrm{F}$. The winter of $1978-1979$, much like the winter of 1981-1982, had record breaking temperatures and heavy snowfall across much of the mid-section of the country in January (Wagner 1979). While both January of 1979 and 1982 had a similar number of wind chill hours, the difference in the overall winter total was in the number of wind chill hours during December and February. December and February of the winter of 1978-1979 had just over double the wind chill hours of the 1981-1982 winter. A similar scenario played out in other locations across the High Plains region as well. 


\section{Recommendations and Conclusions}

Daily and hourly wind chill climatologies were created for the High Plains region of the United States. Hourly data from 57 stations around the region were used to create this dataset. The compilation of hourly data was novel and gives service climatologists, forecasters, and the general public an easier way to understand the frequencies at which extremely low wind chill temperatures occur across the Plains. Overall, the meridional temperature gradient is evident in all months with the more extreme wind chill temperatures experienced in the north and the less extreme in the south. In addition, northern areas of the Plains experience more days at extremely

low wind chills than do southern areas. The month with the highest low wind chill occurrence is January, with December and February having nearly identical occurrence rates.

There are many options for future research with an hourly dataset. For instance, the trend in wind chill over this 40-year period was briefly analyzed and it was found that there is a decreasing trend through time. More analyses must be completed in order to determine whether or not these results are significant and whether the decrease in wind chill occurrence is due to an increase in temperature, a decrease in winds, or both. Another related avenue for research could be an investigation into the dominant driver (either temperature or wind speed) of low wind chills in the High Plains. Additionally, the wind chill dataset could also be expanded both spatially and temporally to include other states to the east and non-winter months, such as November and March for the northern tier states. Complementary to the wind chill climatology, an analysis of heat indices in the High Plains could also be useful.

Note: The entire set of wind chill maps may be found at www.hprcc.unl.edu/maps/windchill. Acknowledgments: 
Funding for this study was provided by the National Oceanic and Atmospheric Administration, Award EA133E-10-CN-0165. Special thanks also go to Dr. Jinsheng You for quality controlling the data used in this study. 


\section{References:}

Ahmad, R.A. and S. Boraas, 2010: Flow and Thermal Errors in Current National Weather Service Wind Chill Models. Heat Transfer Engineering, 31, 1137-1154.

Ames, D. R., and L. W. Insley. 1975: Wind-chill effect for cattle and sheep. J. Anim. Sci. 40, 161-165.

Bluestein, M., 1998: An evaluation of the wind chill factor: Its development and applicability. $J$. Biomech. Eng., 120, 255-258.

-, and J. Zecher, 1999: A new approach to an accurate wind chill factor. Bull. Amer. Meteor. Soc, 80, 1893-1899.

Cressman, G. P., 1959: An operational objective analysis system. Mon. Wea. Rev., 87, 367-374.

Keimig, F. T. and R. S. Bradley, 2002: Recent changes in wind chill temperatures at high latitudes in North America. Geophys. Res. Lett., 29, 1163-1166.

Kessler, E., 1993: Wind chill errors. Bull. Amer. Meteor. Soc., 74, 1743-1744.

Mader, T. L., L. J. Johnson, and J.B. Gaughan, 2010: A comprehensive index for assessing environmental stress in animals. J. Anim. Sci., 88, 2153-2165.

Moore, G. W. K. and J. L. Semple, 2011: Freezing and frostbite on Mount Everest: New insights into wind chill and freezing times at extreme altitude. High Alt. Med. Bio., 12, 271-275.

National Climatic Data Center, cited 2010: Integrated Surface Hourly. [Available online at: http://lwf.ncdc.noaa.gov/oa/climate/climatedata.html.]

Osczevski, R. 1995: The basis of wind chill. Arctic, 48, 372-382.

-, 2000: Windward cooling: An overlooked factor in the calculation of wind chill. Bull. Amer. Meteor. Soc., 81, 2975-2978.

—, and M. Bluestein, 2005: The new wind chill equivalent temperature chart. Bull. 
Amer. Meteor. Soc., 86, 1453-1458.

Rieck, T. and S. Binau, cited 2010: Wind Chill Climatology for the North-Central United States. [Available online at: http://www.crh.noaa.gov/crh/ssd/pdf/tsp_15.pdf.]

Shitzer, A., and P. Tikuisis, 2012: Advances, shortcomings, and recommendations for wind chill estimation. Int. J. of Biometeorol., 56, 495-503.

Shulski, M. D., and J. You, 2011: Meteorological data for the Beaufort and Chukchi Sea Coastal Region of the Arctic: Observing stations and quality control procedures. BOEMRE project report.

Siple, P. A., and C. F. Passel, 1945: Measurements of dry atmospheric cooling in subfreezing temperatures. Proc. Amer. Philos. Soc., 89, 177-199.

Steadman, R. G., 1971: Indices of windchill of clothed persons. J. Appl. Meteor., 10, 674-683.

Wagner, A. J., 1979: Weather and circulation of 1979: Widespread record cold with heavy snowfall in the Midwest. Mon. Wea. Rev., 107, 499-506.

-, 1982: Weather and circulation of 1982: A stormy month with two record cold waves. Mon. Wea. Rev., 110, 310-317. 


\section{Tables:}

\begin{tabular}{|c|c|c|c|c|c|c|c|c|}
\hline \multirow{2}{*}{ 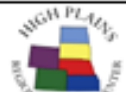 } & \multicolumn{4}{|c|}{ Daily } & \multicolumn{4}{|c|}{ Hourly } \\
\hline & December & January & February & Year & December & January & February & Year \\
\hline$\leq-10^{\circ} \mathrm{F}$ & $\begin{array}{l}\text { Days per } \\
\text { December } \\
\text { with wind } \\
\text { chills } \\
\leq-10^{\circ} \mathrm{F}\end{array}$ & $\begin{array}{l}\text { Days per } \\
\text { January } \\
\text { with wind } \\
\text { chills } \\
\leq-10^{\circ} \mathrm{F}\end{array}$ & $\begin{array}{l}\text { Days per } \\
\text { February } \\
\text { with wind } \\
\text { chills } \\
\leq-10^{\circ} \mathrm{F}\end{array}$ & $\begin{array}{l}\text { Days per } \\
\text { Year with } \\
\text { wind } \\
\text { chills } \\
\leq-10^{\circ} \mathrm{F}\end{array}$ & $\begin{array}{l}\text { Hours per } \\
\text { December } \\
\text { with wind } \\
\text { chills } \\
\leq-10^{\circ} \mathrm{F}\end{array}$ & $\begin{array}{l}\text { Hours per } \\
\text { January } \\
\text { with wind } \\
\text { chills } \\
\leq-10^{\circ} \mathrm{F}\end{array}$ & $\begin{array}{l}\text { Hours per } \\
\text { February } \\
\text { with wind } \\
\text { chills } \\
\leq-10^{\circ} \mathrm{F}\end{array}$ & $\begin{array}{l}\text { Hours per } \\
\text { Year with } \\
\text { wind chills } \\
\leq-10^{\circ} \mathrm{F}\end{array}$ \\
\hline$\leq-15^{\circ} \mathrm{F}$ & $\begin{array}{l}\text { Days per } \\
\text { December } \\
\text { with wind } \\
\text { chills } \\
\leq-15^{\circ} \mathrm{F}\end{array}$ & $\begin{array}{l}\text { Days per } \\
\text { January } \\
\text { with wind } \\
\text { chills } \\
\leq-15^{\circ} \mathrm{F}\end{array}$ & $\begin{array}{l}\text { Days per } \\
\text { February } \\
\text { with wind } \\
\text { chills } \\
\leq-15^{\circ} \mathrm{F}\end{array}$ & $\begin{array}{l}\text { Days per } \\
\text { Year with } \\
\text { wind } \\
\text { chills } \\
\leq-15^{\circ} \mathrm{F}\end{array}$ & $\begin{array}{l}\text { Hours per } \\
\text { December } \\
\text { with wind } \\
\text { chills } \\
\leq-15^{\circ} \mathrm{F}\end{array}$ & $\begin{array}{l}\text { Hours per } \\
\text { January } \\
\text { with wind } \\
\text { chills } \\
\leq-15^{\circ} \mathrm{F}\end{array}$ & $\begin{array}{l}\text { Hours per } \\
\text { February } \\
\text { with wind } \\
\text { chills } \\
\leq-15^{\circ} \mathrm{F}\end{array}$ & $\begin{array}{l}\text { Hours per } \\
\text { Year with } \\
\text { wind chills } \\
\leq-15^{\circ} \mathrm{F}\end{array}$ \\
\hline$\leq-20^{\circ} \mathrm{F}$ & $\begin{array}{l}\text { Days per } \\
\text { December } \\
\text { with wind } \\
\text { chills } \\
\leq-20^{\circ} \mathrm{F}\end{array}$ & $\begin{array}{l}\text { Days per } \\
\text { January } \\
\text { with wind } \\
\text { chills } \\
\leq-20^{\circ} \mathrm{F}\end{array}$ & $\begin{array}{l}\text { Days per } \\
\text { February } \\
\text { with wind } \\
\text { chills } \\
\leq-20^{\circ} \mathrm{F}\end{array}$ & $\begin{array}{l}\text { Days per } \\
\text { Year with } \\
\text { wind } \\
\text { chills } \\
\leq-20^{\circ} \mathrm{F}\end{array}$ & $\begin{array}{l}\text { Hours per } \\
\text { December } \\
\text { with wind } \\
\text { chills } \\
\leq-20^{\circ} \mathrm{F}\end{array}$ & $\begin{array}{l}\text { Hours per } \\
\text { January } \\
\text { with wind } \\
\text { chills } \\
\leq-20^{\circ} \mathrm{F}\end{array}$ & $\begin{array}{l}\text { Hours per } \\
\text { February } \\
\text { with wind } \\
\text { chills } \\
\leq-20^{\circ} \mathrm{F}\end{array}$ & $\begin{array}{l}\text { Hours per } \\
\text { Year with } \\
\text { wind chills } \\
\leq-20^{\circ} \mathrm{F}\end{array}$ \\
\hline$\leq-25^{\circ} \mathrm{F}$ & $\begin{array}{l}\text { Days per } \\
\text { December } \\
\text { with wind } \\
\text { chills } \\
\leq-25^{\circ} \mathrm{F}\end{array}$ & $\begin{array}{l}\text { Days per } \\
\text { January } \\
\text { with wind } \\
\text { chills } \\
\leq-25^{\circ} \mathrm{F}\end{array}$ & $\begin{array}{l}\text { Days per } \\
\text { February } \\
\text { with wind } \\
\text { chills } \\
\leq-25^{\circ} \mathrm{F}\end{array}$ & $\begin{array}{l}\text { Days per } \\
\text { Year with } \\
\text { wind } \\
\text { chills } \\
\leq-25^{\circ} \mathrm{F}\end{array}$ & $\begin{array}{l}\text { Hours per } \\
\text { December } \\
\text { with wind } \\
\text { chills } \\
\leq-25^{\circ} \mathrm{F}\end{array}$ & $\begin{array}{l}\text { Hours per } \\
\text { January } \\
\text { with wind } \\
\text { chills } \\
\leq-25^{\circ} \mathrm{F}\end{array}$ & $\begin{array}{l}\text { Hours per } \\
\text { February } \\
\text { with wind } \\
\text { chills } \\
\leq-25^{\circ} \mathrm{F}\end{array}$ & $\begin{array}{l}\text { Hours per } \\
\text { Year with } \\
\text { wind chills } \\
\leq-25^{\circ} \mathrm{F}\end{array}$ \\
\hline$\leq-30^{\circ} \mathrm{F}$ & $\begin{array}{l}\text { Days per } \\
\text { December } \\
\text { with wind } \\
\text { chills } \\
\leq-30^{\circ} \mathrm{F}\end{array}$ & $\begin{array}{l}\text { Days per } \\
\text { January } \\
\text { with wind } \\
\text { chills } \\
\leq-30^{\circ} \mathrm{F}\end{array}$ & $\begin{array}{l}\text { Days per } \\
\text { February } \\
\text { with wind } \\
\text { chills } \\
\leq-30^{\circ} \mathrm{F}\end{array}$ & $\begin{array}{l}\text { Days per } \\
\text { Year with } \\
\text { wind } \\
\text { chills } \\
\leq-30^{\circ} \mathrm{F}\end{array}$ & $\begin{array}{l}\text { Hours per } \\
\text { December } \\
\text { with wind } \\
\text { chills } \\
\leq-30^{\circ} \mathrm{F}\end{array}$ & $\begin{array}{l}\text { Hours per } \\
\text { January } \\
\text { with wind } \\
\text { chills } \\
\leq-30^{\circ} \mathrm{F}\end{array}$ & $\begin{array}{l}\text { Hours per } \\
\text { February } \\
\text { with wind } \\
\text { chills } \\
\leq-30^{\circ} \mathrm{F}\end{array}$ & $\begin{array}{l}\text { Hours per } \\
\text { Year with } \\
\text { wind chills } \\
\leq-30^{\circ} \mathrm{F}\end{array}$ \\
\hline$\leq-35^{\circ} \mathrm{F}$ & $\begin{array}{l}\text { Days per } \\
\text { December } \\
\text { with wind } \\
\text { chills } \\
\leq-35^{\circ} \mathrm{F}\end{array}$ & $\begin{array}{l}\text { Days per } \\
\text { January } \\
\text { with wind } \\
\text { chills } \\
\leq-35^{\circ} \mathrm{F}\end{array}$ & $\begin{array}{l}\text { Days per } \\
\text { February } \\
\text { with wind } \\
\text { chills } \\
\leq-35^{\circ} \mathrm{F}\end{array}$ & $\begin{array}{l}\text { Days per } \\
\text { Year with } \\
\text { wind } \\
\text { chills } \\
\leq-35^{\circ} \mathrm{F}\end{array}$ & $\begin{array}{l}\text { Hours per } \\
\text { December } \\
\text { with wind } \\
\text { chills } \\
\leq-35^{\circ} \mathrm{F}\end{array}$ & $\begin{array}{l}\text { Hours per } \\
\text { January } \\
\text { with wind } \\
\text { chills } \\
\leq-35^{\circ} \mathrm{F}\end{array}$ & $\begin{array}{l}\text { Hours per } \\
\text { February } \\
\text { with wind } \\
\text { chills } \\
\leq-35^{\circ} \mathrm{F}\end{array}$ & $\begin{array}{l}\text { Hours per } \\
\text { Year with } \\
\text { wind chills } \\
\leq-35^{\circ} \mathrm{F}\end{array}$ \\
\hline$\leq-40^{\circ} \mathrm{F}$ & $\begin{array}{l}\text { Days per } \\
\text { December } \\
\text { with wind } \\
\text { chills } \\
\leq-40^{\circ} \mathrm{F}\end{array}$ & $\begin{array}{l}\text { Days per } \\
\text { January } \\
\text { with wind } \\
\text { chills } \\
\leq-40^{\circ} \mathrm{F}\end{array}$ & $\begin{array}{l}\text { Days per } \\
\text { February } \\
\text { with wind } \\
\text { chills } \\
\leq-40^{\circ} \mathrm{F}\end{array}$ & $\begin{array}{l}\text { Days per } \\
\text { Year with } \\
\text { wind } \\
\text { chills } \\
\leq-40^{\circ} \mathrm{F}\end{array}$ & $\begin{array}{l}\text { Hours per } \\
\text { December } \\
\text { with wind } \\
\text { chills } \\
\leq-40^{\circ} \mathrm{F}\end{array}$ & $\begin{array}{l}\text { Hours per } \\
\text { January } \\
\text { with wind } \\
\text { chills } \\
\leq-40^{\circ} \mathrm{F}\end{array}$ & $\begin{array}{l}\text { Hours per } \\
\text { February } \\
\text { with wind } \\
\text { chills } \\
\leq-40^{\circ} \mathrm{F}\end{array}$ & $\begin{array}{l}\text { Hours per } \\
\text { Year with } \\
\text { wind chills } \\
\leq-40^{\circ} \mathrm{F}\end{array}$ \\
\hline
\end{tabular}

Table 1. List of the maps made in this study. 


\section{Figures:}

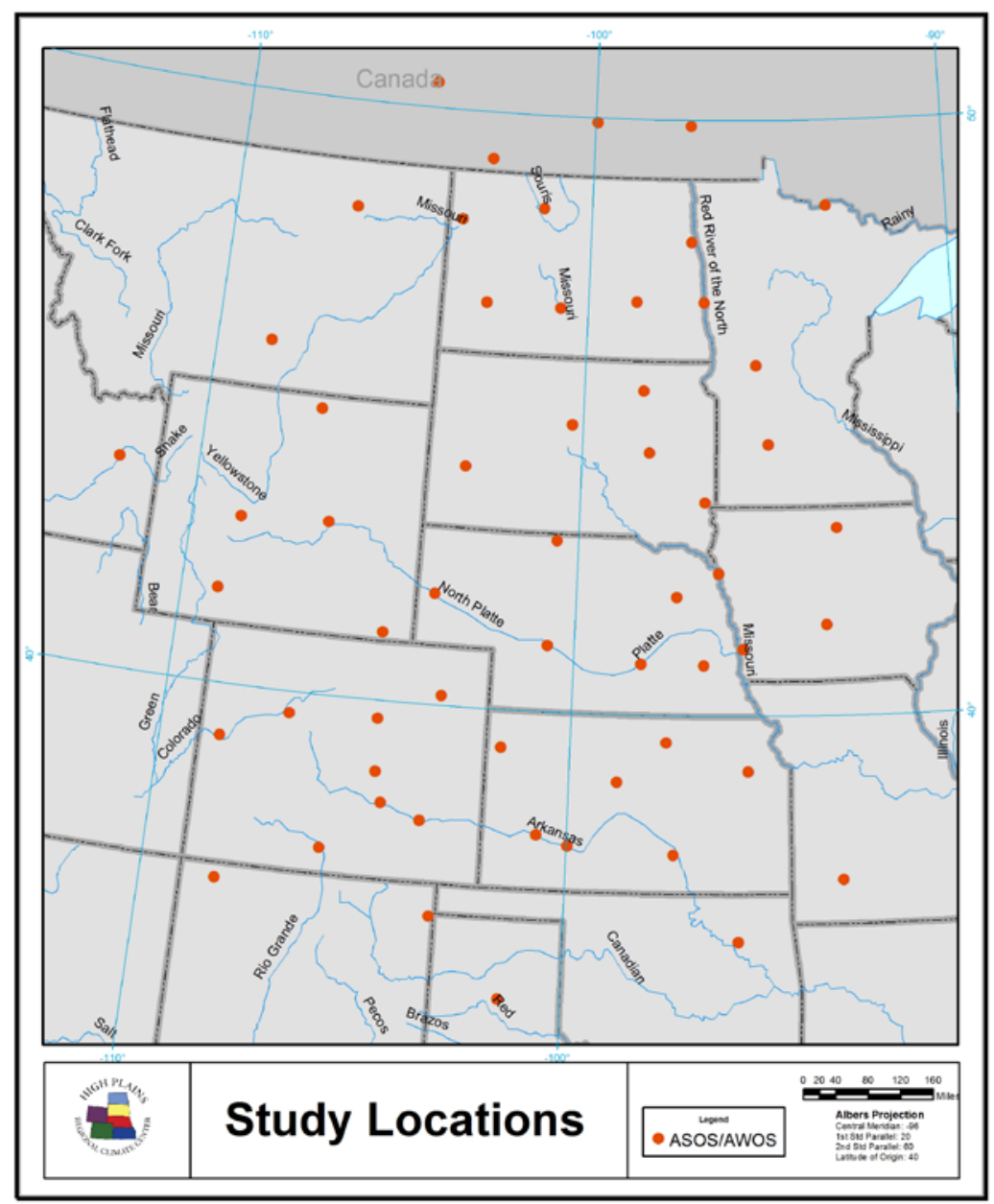

Figure 1. Location of the 57 quality-controlled stations used in the study. 


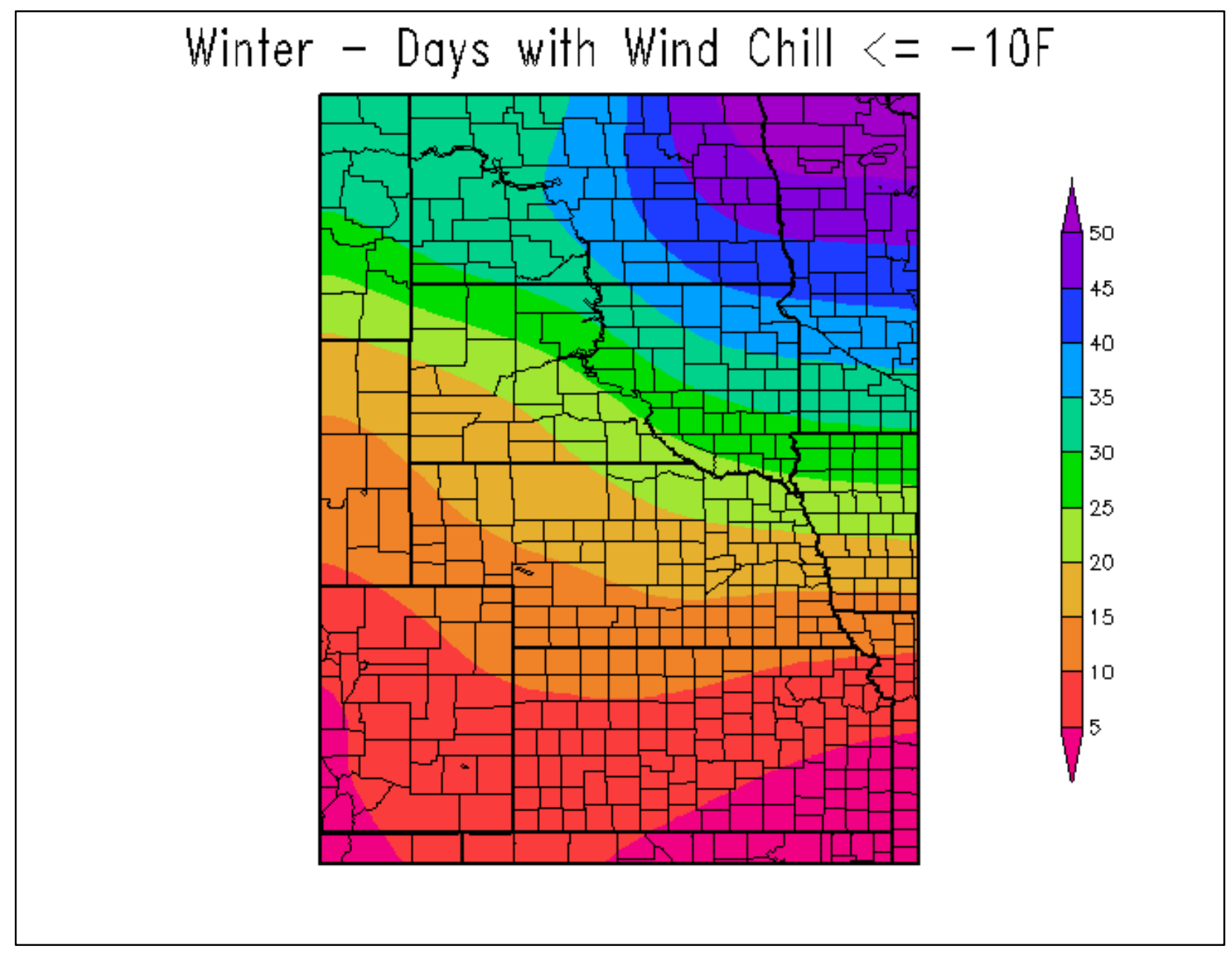

Figure 2. Days per winter with wind chill temperatures at or below $-10^{\circ} \mathrm{F}$. 


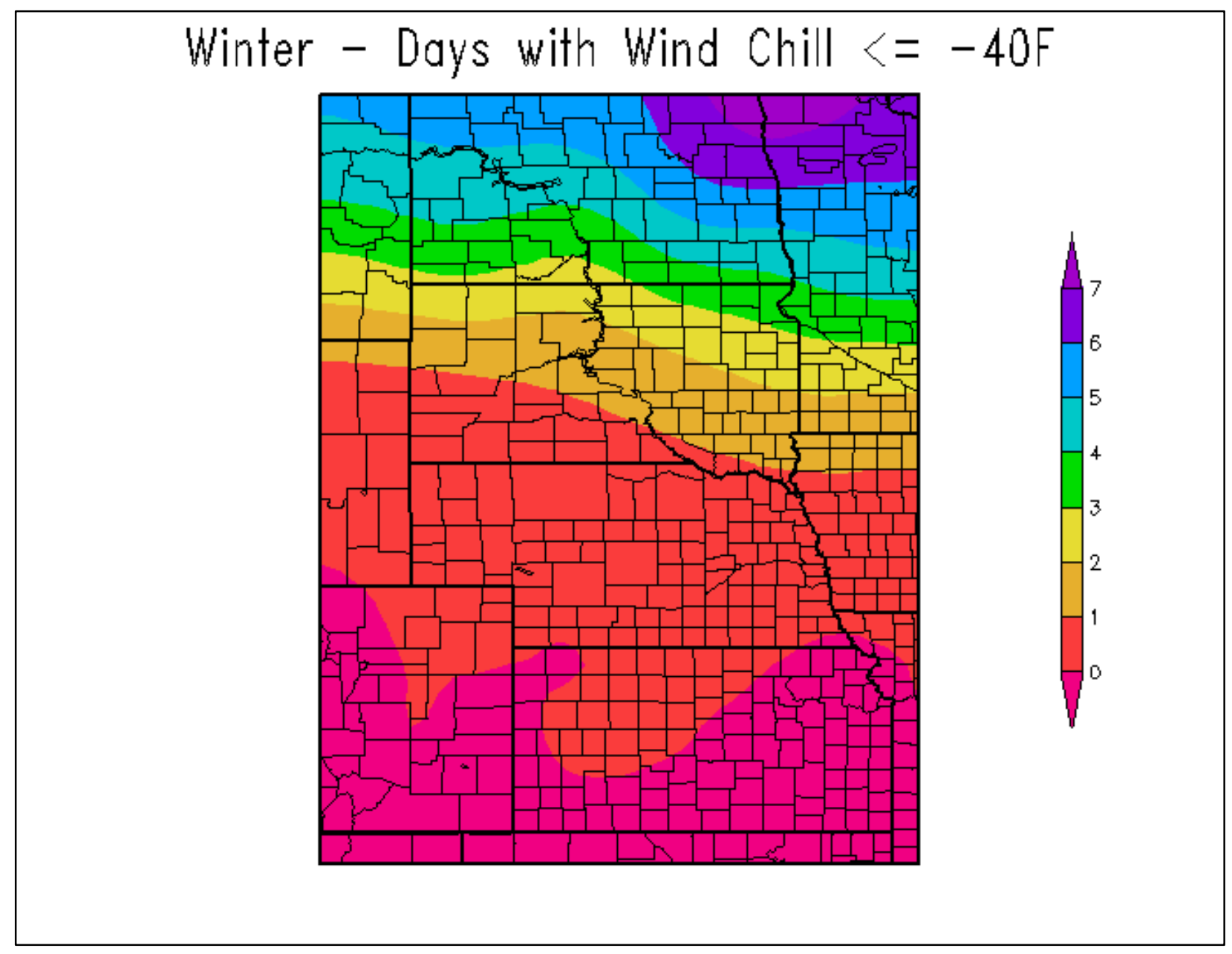

Figure 3. Days per winter with wind chill temperatures at or below $-40^{\circ} \mathrm{F}$. 


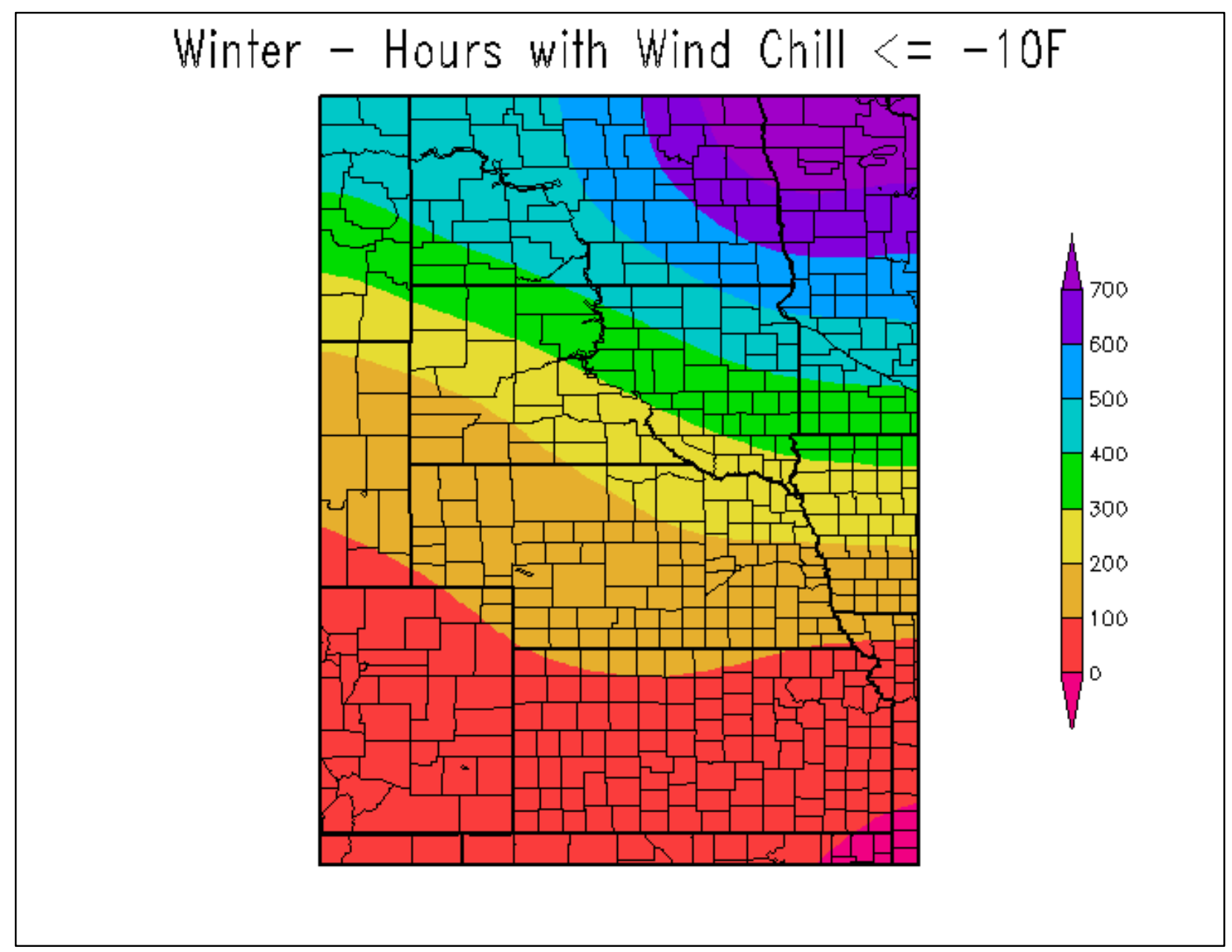

Figure 4. Hours per winter with wind chill temperatures at or below $-10^{\circ} \mathrm{F}$. 


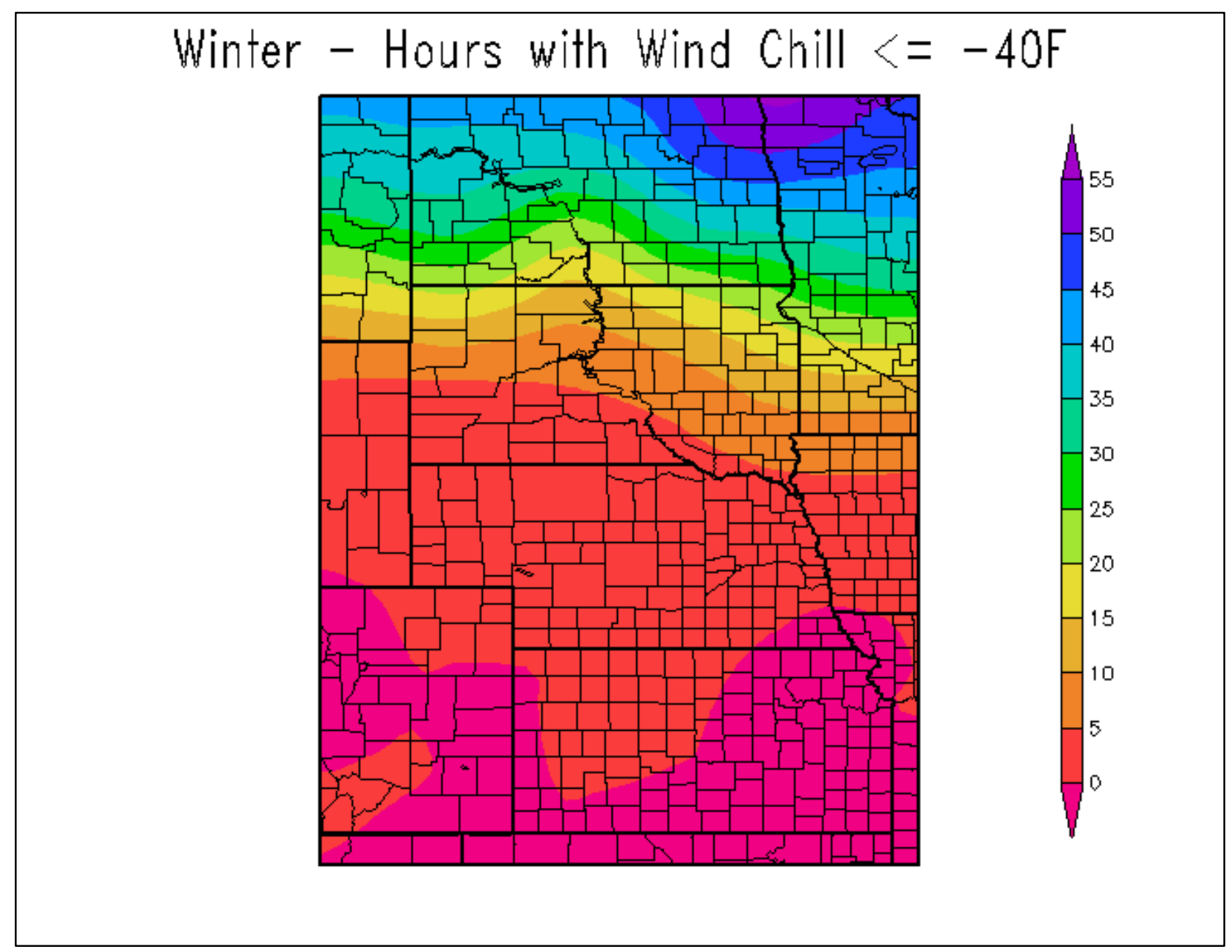

Figure 5. Hours per winter with wind chill temperatures at or below $-40^{\circ} \mathrm{F}$. 


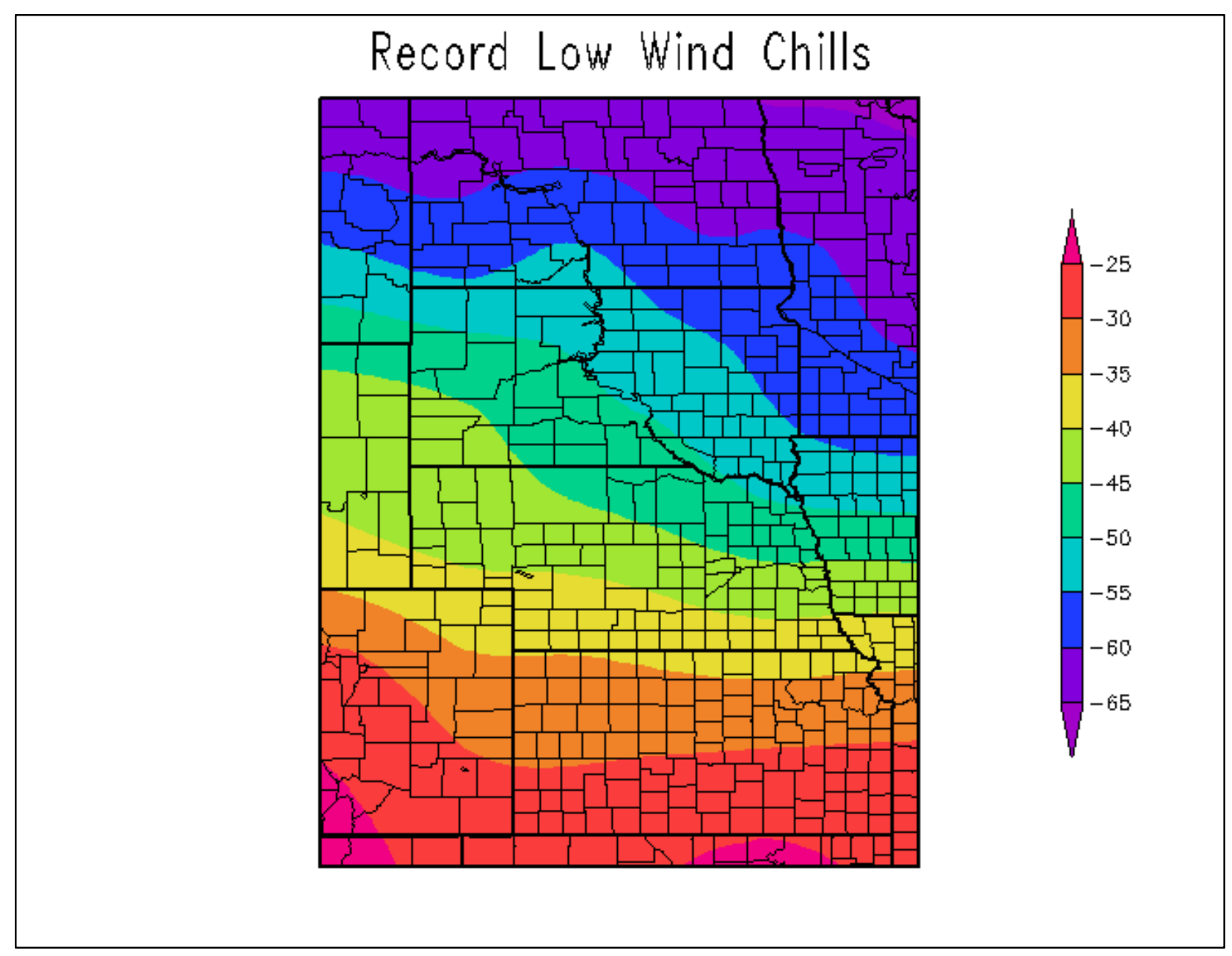

Figure 6. Record low wind chill temperatures $\left({ }^{\circ} \mathrm{F}\right)$ during the period of analysis for the High Plains region. 


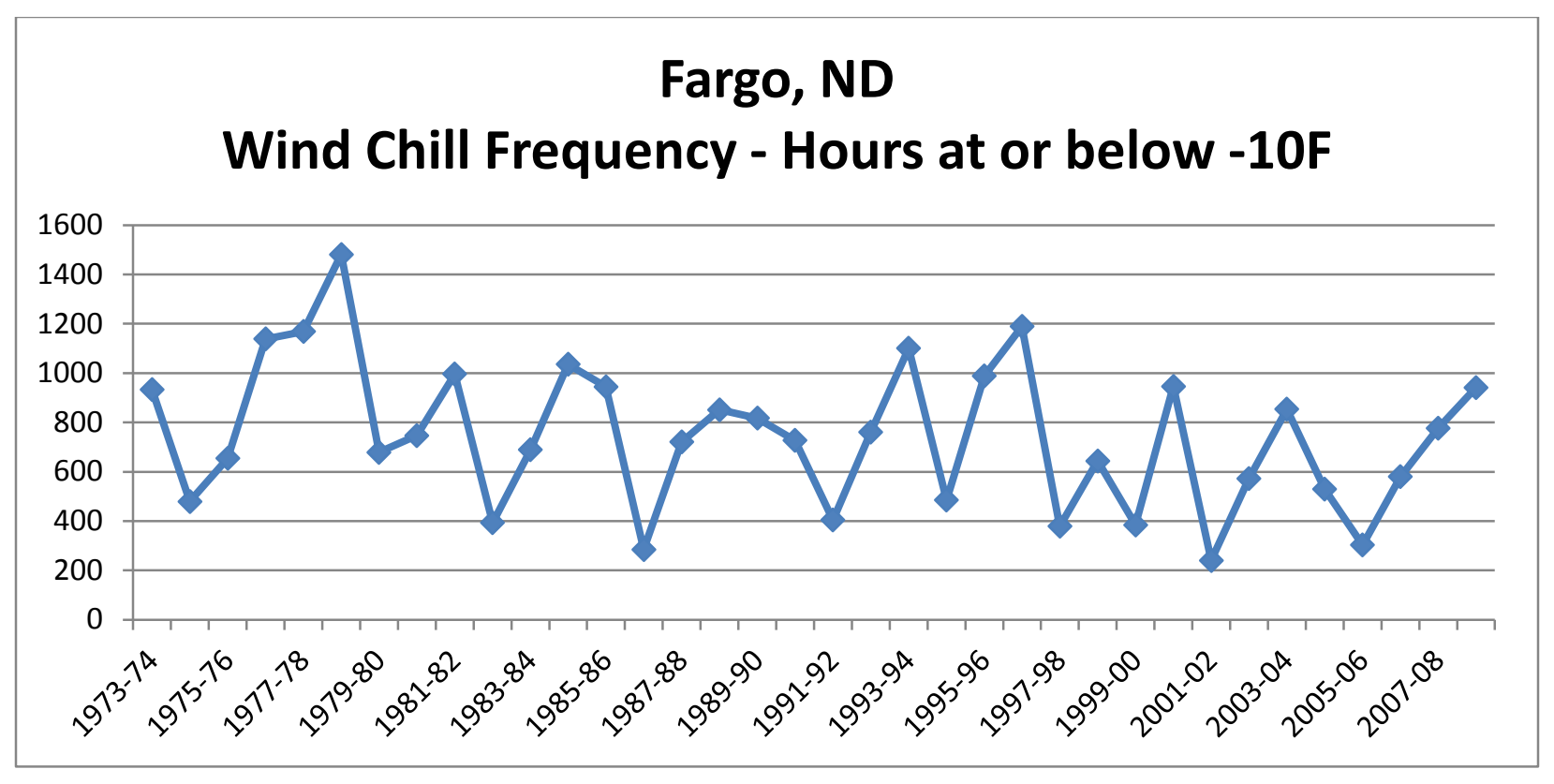

Figure 7. Frequency of wind chill hours at or below $-10^{\circ} \mathrm{F}$ by winter season in Fargo, ND. 